\title{
POSTNATAL DEVELOPMENT OF THE BENZODIAZEPINE AND GABA RECEPTORS IN THE RAT SPINAL CORD
}

\author{
Ken-ichi SAITO, Masayoshi GOTO and Hideomi FUKUDA \\ Department of Toxicology and Pharmacology, Faculty of Pharmaceutical Sciences. \\ The University of Tokyo, Bunkyo-ku, Tokyo 113, Japan
}

Accepted May 6, 1983

The binding of benzodiazepines (BZDs) to the specific receptors in the central nervous system appears to mediate the pharmacological actions of these drugs (1-3), and much evidence (4-8) suggests that these receptors interact with some $\gamma$-aminobutyric acid (GABA) receptors. We have previously reported the postnatal development of the GABA system in the rat spinal cord (9). In the present study, we investigated the postnatal development of $\left[{ }^{3} \mathrm{H}\right]$ diazepam and $\left[{ }^{3} \mathrm{H}\right]$ muscimol binding, as well as the effect of GABA on the BZD receptors in the spinal cord, in comparison with those in the cerebellum, because the developmental pattern of the GABA system in the rat spinal cord was markedly different from that in the brain (9).

Experiments were performed on male Wistar rats, but for the study on 1 day-old rats, both sexes were used. The pups were reduced to a maximum of ten per litter $24 \mathrm{hr}$ after birth. These animals were exanguinated, and the dorsal areas of spinal cords and cerebella were quickly removed and pooled at $-70^{\circ} \mathrm{C}$ until sufficient material was obtained to perform the binding assay.

Crude synaptic membranes were obtained by the method of Zukin et al. (10). The membrane was resuspended in ice-cold Tris buffer $(50 \mathrm{mM}$ Tris citrate, $\mathrm{pH} \mathrm{7.1}$, at $4^{\circ} \mathrm{C}$ and $50 \mathrm{mM}$ Tris $\mathrm{HCl}$. pH 7.4 , at $4^{\circ} \mathrm{C}$ for $\left[{ }^{3} \mathrm{H}\right]$ muscimol and $\left[{ }^{3} \mathrm{H}\right]$ diazepam binding, respectively, recentrifuged at $48,000 \mathrm{~g}$ for $20 \mathrm{~min}$, and then pooled and kept at $-70^{\circ} \mathrm{C}$ at least $16 \mathrm{hr}$. The frozen membrane was thawed, and suspended in $50 \mathrm{mM}$ Tris buffer and centrifuged at $48.000 \mathrm{~g}$ for $20 \mathrm{~min}$, after which this procedure was repeated twice.

$\left[{ }^{3} \mathrm{H}\right]$ Muscimol binding was performed as previously described (9). The amount of protein in each assay mixture was $0.13-0.83$ mg. The $\left[{ }^{3} \mathrm{H}\right]$ diazepam binding assay was conducted as follows: Duplicate aliquots $(0.1 \mathrm{ml})$ of membrane suspension $(0.11-$ $0.57 \mathrm{mg}$ protein) were incubated with $1 \mathrm{nM}$ $\left[{ }^{3} \mathrm{H}\right]$ diazepam in the presence and absence of $10^{-4} \mathrm{MGABA}$ for $40 \mathrm{~min}$ at $0-4^{\circ} \mathrm{C}$ in a total volume of $0.5 \mathrm{ml}$. After incubation, the samples were rapidly filtered under vacuum through Whatman GF/B filters. Specific binding was defined as the difference between total binding and the binding in the presence of $3 \mu \mathrm{M}$ diazepam. The concentrations of $\left[{ }^{3} \mathrm{H}\right]$ muscimol and $\left[{ }^{3} \mathrm{H}\right]$ diazepam used for Scatchard analyses were $0.4-80.0$ and $0.2-$ $16.0 \mathrm{nM}$. respectively. Protein was measured according to the method of Lowry et al. (11). Statistical analysis was performed using Student's $t$-test (two-tailed).

[Methylamine- ${ }^{3} \mathrm{H}$ ] muscimol $(9.5-19.0 \mathrm{Ci} /$ $\mathrm{mmol})$ and $[\mathrm{N}$-methyl-3H]diazepam (76.8$94.0 \mathrm{Ci} / \mathrm{mmol}$ ) were purchased from the Radiochemical Centre, Amersham. Diazepam was a gift from the Sumitomo Chem. Co.

Table 1 shows the postnatal development of $\left[{ }^{3} \mathrm{H}\right]$-diazepam and $\left[{ }^{3} \mathrm{H}\right]$ muscimol binding in the dorsal area of the rat spinal cord, in which the density of GABA receptors was higher than in the ventral area (9). Scatchard 
Table 1. $\left[{ }^{3} \mathrm{H}\right]$ diazepam and $\left[{ }^{3} \mathrm{H}\right]$ muscimol binding in the spinal cord and cerebellum during development

\begin{tabular}{|c|c|c|c|c|c|c|c|c|}
\hline \multirow{3}{*}{$\begin{array}{l}\text { Ago } \\
\text { (days) }\end{array}$} & \multicolumn{4}{|c|}{ Spinal cord } & \multicolumn{4}{|c|}{ Cerebellum } \\
\hline & \multicolumn{2}{|c|}{$\left[{ }^{3} \mathrm{H}\right]$ diazepam } & \multicolumn{2}{|c|}{$\left[{ }^{3} \mathrm{H}\right] \mathrm{muscimol}$} & \multicolumn{2}{|c|}{$\left[{ }^{3} \mathrm{H}\right]$ diazepam } & \multicolumn{2}{|c|}{$\left[{ }^{3} H\right]$ muscimol } \\
\hline & $K_{11}$ & $B_{\max }$ & $K_{n l}$ & $B_{\max }$ & $K_{11}$ & $B_{\max }$ & $K_{d}$ & $B_{111:}$ \\
\hline 1 & $6.2 \pm 0.6$ & $\begin{array}{c}1.64 \pm 0.13^{* * *} \\
(482.4)\end{array}$ & $7.9 \pm 1.8$ & $\begin{array}{r}0.35 \pm 0.11 \\
(291.7)\end{array}$ & $7.0 \pm 0.8$ & $\begin{array}{r}0.53 \pm 0.11 \\
(53.0)\end{array}$ & $10.1 \pm 1.7$ & $\begin{array}{c}0.16 \pm 0.03 \\
(10.6)\end{array}$ \\
\hline 8 & $6.4 \pm 0.4$ & $\begin{array}{c}1.42 \text { 上0.03 } \\
(417.6)\end{array}$ & $7.6 \pm 1.2$ & $\begin{array}{c}0.71 \pm 0.11^{* *} \\
(591.7)\end{array}$ & $8.9 \pm 1.0$ & $\begin{array}{r}0.69 \pm 0.21 \\
(69.0)\end{array}$ & $9.4 \perp 1.5$ & $\begin{array}{r}0.52 \pm 0.14 \\
(34.4)\end{array}$ \\
\hline 15 & $7.1=0.6$ & $\begin{array}{c}0.89 \pm 0.09^{* *} \\
(261.8)\end{array}$ & $5.7 \pm 1.1$ & $\begin{array}{c}0.31 \pm 0.04^{*} \\
(258.3)\end{array}$ & $8.7+0.6$ & $\begin{array}{r}0.86 \pm 0.04 \\
(86.0)\end{array}$ & $8.4 \pm 2.2$ & $\begin{array}{c}0.58 \pm 0.06 \\
(38.4)\end{array}$ \\
\hline 22 & $7.0 \pm 0.4$ & $\begin{array}{c}0.66 \pm 0.10^{*} \\
(194.1)\end{array}$ & $5.9 \pm 0.5^{*}$ & $\begin{array}{c}0.13 \pm 0.06 \\
(108.3)\end{array}$ & $8.6 \pm 0.2$ & $\begin{array}{c}1.10 \pm 0.16 \\
(110.0)\end{array}$ & $10.8 \pm 4.2$ & $\begin{array}{r}1.67 \pm 0.47 \\
(110.6)\end{array}$ \\
\hline 60 & $5.9 \pm 0.6$ & $\begin{array}{c}0.34 \pm 0.02 \\
(100.0)\end{array}$ & $3.9 \pm 0.5$ & $\begin{array}{r}0.12 \pm 0.02 \\
(100.0)\end{array}$ & $8.1 \pm 0.7$ & $\begin{array}{c}1.00 \pm 0.19 \\
(100.0)\end{array}$ & $6.2 \pm 2.1$ & $\begin{array}{c}1.51 \pm 0.34 \\
(100.0)\end{array}$ \\
\hline
\end{tabular}

$K_{d}(n M)$ and $B_{m: x}$ (pmol/mg protein) were determined by Scatchard analysis of saturation isotherms. The data represent the mean of 3 values. with the S.E.M. indicated. Values in parentheses are percentages of adult levels. ${ }^{*} \mathrm{P}<0.05,{ }^{*} \mathrm{P}<0.01,{ }^{* *} \mathrm{P}<0.001$, compared to the adult rats (60 days).

Table 2. Effocts of GABA on the $\left[{ }^{3} \mathrm{H}\right]$ diazepam binding during development

\begin{tabular}{|c|c|c|c|c|c|c|}
\hline \multirow{2}{*}{$\begin{array}{c}\text { Age } \\
\text { (days) }\end{array}$} & \multicolumn{3}{|c|}{ Spinal cord } & \multicolumn{3}{|c|}{ Cerebellum } \\
\hline & \multicolumn{2}{|c|}{ (fmol/mg protein) } & $\begin{array}{l}\% \text { increase } \\
\text { from control }\end{array}$ & \multicolumn{2}{|c|}{ (fmol/mg protein) } & $\begin{array}{l}\% \text { increase } \\
\text { from control }\end{array}$ \\
\hline 1 & $166.6+26.1$ & $371.7 \pm 46.9$ & $128.8 \pm 13.4(4)$ & $57.1 \pm 15.3$ & $118.4 \pm 19.0$ & $117.7 \pm 21.5(3)$ \\
\hline 8 & $189.7 \pm 29.8$ & $398.9 \pm 45.1$ & $116.6 \pm 17.6(4)$ & $64.0 \pm 15.8$ & $140.5 \pm 38.3$ & $116.9 \pm 7.0(3)$ \\
\hline 15 & $104.2 \pm 20.8$ & $227.4 \pm 46.5$ & $118.5 \pm 4.4(4)$ & $90.0 \pm 6.5$ & $190.7 \pm 24.8$ & $110.9 \pm 15.4(3)$ \\
\hline 22 & $69.0 \pm 5.7$ & $179.6 \pm 32.2$ & $155.8 \pm 29.5(4)$ & $107.1 \pm 15.5$ & $242.0 \pm 53.5$ & $121.4 \pm 16.2(3)$ \\
\hline 60 & $41.7 \pm 8.0$ & $96.7 \pm 11.9$ & $144.0121 .8(4)$ & $102.4 \pm 11.0$ & $218.2 \pm 3.3$ & $117.2 \pm 18.8(3)$ \\
\hline
\end{tabular}

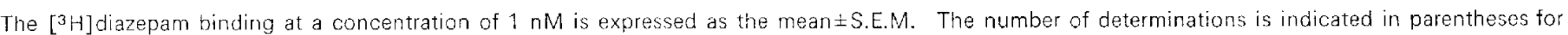
each age. 
analyses indicated that while the dissociation constants $\left(\mathrm{K}_{\mathrm{d}}\right)$ of $\left[{ }^{3} \mathrm{H}\right]$ diazepam and $\left[{ }^{3} \mathrm{H}\right]$ muscimol binding sites remained unchanged during development, the number of binding sites $\left(B_{\max }\right)$ changed with age.

In 1 day-old rats, the number of $\left[{ }^{3} \mathrm{H}\right]$ diazepam binding sites, expressed as pmol per $\mathrm{mg}$ protein, was 5 times as high as that in the adult rats, and this decreased progressively from 8 days. The number of $\left[{ }^{3} \mathrm{H}\right]$ muscimol binding sites was 3 times as high as that in adults on 1 day. increased to a peak at 8 days and declined until the 22 nd day when the levels reached those seen in the adults.

In the cerebellum, as seen in the spinal cord, postnatal development of $\left[{ }^{3} \mathrm{H}\right]$ diazepam and $\left[{ }^{3} \mathrm{H}\right]$ muscimol binding was the change of the number of binding sites (Table 1). At 1 day, the number of $\left[{ }^{3} \mathrm{H}\right]$ diazepam binding sites was $50 \%$ of adult levels, increased with age and reached adult values at the 22 nd day. On the other hand, the number of $\left[{ }^{3} \mathrm{H}\right]$ muscimol binding sites was very low in 1 day-old rats, followed by a rapid increase until 8 days: afterwards, the level was little changed until 15 days and increased about 3 times from 15 to 22 days.

We have previously reported that the developmental pattern of the GABA system in the rat spinal cord was markedly different from that in the brain (9). In this study, we clarified that the postnatal development of the $B Z D$ and GABA receptors was different from that in the cerebellum. In each area, however, the developmental patterns of the $B Z D$ and GABA receptors were similar, except for 1 day after birth. when the $B_{\max }$ of the $B Z D$ receptors was rather high. The reason for this high level of the BZD receptors on 1 day was not clear in this study. but Candy and Martin (12) reported that the $B Z D$ receptors at early postnatal stages were higher than receptors for other neuro. transmitters.
In the spina! cord, GABA enhanced $\left[{ }^{3} \mathrm{H}\right]$ diazepam binding dose-dependently: maximum response was obtained at $10^{-4} \mathrm{M}$, and the concentration required to produce a half-maximum stimulation of $\left[{ }^{3} \mathrm{H}\right]$ diazepam binding was $1.5 \times 10^{-6} \mathrm{M}$. The magnitude of the increase of $\left[{ }^{3} \mathrm{H}\right]$ diazepam binding by $10^{-4} \mathrm{M}$ GABA was roughly the same throughout development in the spinal cord and cerebellum (Table 2). This result is in good agreement with the data of Palacios et al. (13) and Regan et al. (14). The $B_{\max }$ for the GABA receptors on 1 day was very low in the cerebellum, whereas in the spinal cord, this value was higher than that in the adults. These results may support the idea that GABA exerts its effect on the BZD receptors through some site distinct from the one measured in the muscimol binding studies $(15,16)$. Alternatively, the characteristics of $\left[{ }^{3} \mathrm{H}\right]$ muscimol binding. as measured by binding assay, may not accurately reflect that of the GABA receptors linked to the BZD receptors.

Acknowledgement: This work was supported in part by a Grant-in-Aid for Scientific Research from the Ministry of Education, Science and Culture, Jaoan.

\section{References}

1) Squires, R.F. and Braestrup, C.: Benzodiazepine receptors in rat brain. Nature 266, 732-734 (1977)

2) Möhler, H. and Okada, T.: Benzodiazepine receptor: Demonstration in the central nervous system. Science 198, 849-851 (1977)

3) Braestrup, C. and Squires, R.F.: Pharmacological characterization of benzodiazepine receptors in the brain. Eur. J. Pharmacol. 48, 263-270 (1978)

4) Tallman, J.F., Thomas, J.W. and Gallager, D.W.: GABAergic modulation of benzodiazepine binding site sensitivity. Na:ure 274, 383-385 (1978)

5) Guidotti, A., Toffano, G. and Costa, E.: An endogenous protein modulates the affinity of GABA and benzodiazepine receptors in rat brain. Nature 275, 553-555 (1978) 
6) Gavish, M. and Snyder, S.H.: Benzodiazepine recognition sites on GABA receptors. Nature 287, 651-657 (1980)

7) Matsumoto, K. and Fukuda, H.: Stimulatory and protective effects of benzodiazepines on GABA receptors labeled with $\left[{ }^{3} \mathrm{H}\right]$ muscimol. Life Sci. 30, 935-943(1982)

8) Ito, Y. and Kuriyama, K.: Some properties of solubilized GABA receptor. Brain Res. 236, 351-363(1982)

9) Saito, K., Goto, M. and Fukuda, H.: Postnatal development of the GABA system in the rat spinal cord. Japan. J. Pharmacol. 32, 1-7 (1982)

10) Zukin, S.R., Young, A.B. and Snyder, S.H.: Gamma-aminobutyric acid binding to receptor sites in the rat central nervous system. Proc. Natl. Acad. Sci. U.S.A. 71, 4802-4807 (1974)

11) Lowry, O.H., Rosebrough, N.J., Farr, A.L. and Randall, R.J.: Protein measurement with the Folin phenol reagent. J. Biol. Chem. 193, 265275 (1951)

12) Candy, J.M. and Martin, I.L.: The postnatal development of the benzodiazepine receptor in the cerebral cortex and cerebellum of the rat. J. Neurochem. 32, 655-658 (1979)

13) Palacios, J.M. Niehoff, D.L. and Kuhar, M.J.: Ontogeny of GABA and benzodiazepine receptors: Effects of Triton $X-100$, bromide and muscimol. Brain Res. 179, 390-395 (1979)

14) Regan, J.W., Roeske, W.R. and Yamamura, H.I.: The benzodiazepine receptor: Its development and its modulaton by $\gamma$-aminobutyric acid. J. Pharmacol. Exp. Ther. 212, 137-143 (1980)

15) Karobath, M., Placheta, P., Lippitsch, M. and Krogsgaard-Larsen, P.: Characterization of GABA-stimulated benzodiazepine receptor binding. Adv. Biochem. Psychopharmacol. 21, 313-320 (1980)

16) Marangos, P.J. and Martino, A.M.: Studies of the relationship of $\gamma$-aminobutyric acidstimulated diazepam binding and the $\gamma$-aminobutyric acid receptor. Mol. Pharmacol. 20, 16-21 (1981) 